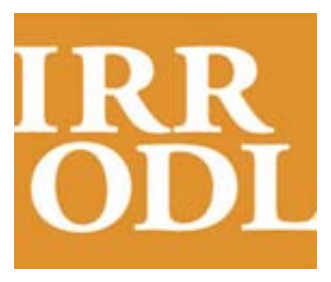

International

Review of

Research in Open

and Distance

Learning

Vol. 12.2

February - 2011

\section{Mobile Learning via SMS at Open University Malaysia: Equitable, Effective, and Sustainable}

Tina Lim, Mansor Fadzil, and Norziati Mansor

Open University Malaysia, Malaysia

\begin{abstract}
This article describes Open University Malaysia's efforts at enhancing the blended learning approach for undergraduate distance learners with the successful implementation of the Mobile Learning via SMS initiative. The pilot project was implemented in the May 2009 semester, and this coming January 2011 semester will be in its sixth consecutive semester. Aspects such as the conceptual model, the process flow of group messaging, and challenges faced, as well as effectiveness of the initiative, are discussed.
\end{abstract}

Keywords: Distance education; mobile learning; SMS; text messaging; enhanced blended learning 


\section{Introduction}

True to the university's vision of being the leader in flexible learning, Open University Malaysia (OUM), Malaysia's first open and distance learning institution of higher education, embarked on a Mobile Learning via SMS initiative in an effort to support distance learners, who are mostly working adults, and to make learning more flexible and ubiquitous for them. The initiative may be considered the first and only one of its kind that has successfully been implemented on a large scale (to date involving an approximate total of 13,200 learners) by a Malaysian higher education institution. The general objectives of mobile learning are

1. to enhance the blend of learning modes at OUM;

2. to increase the flexibility of learning offered to OUM learners; and

3. to encourage and support ubiquitous learning (just in time, anytime, anywhere) via mobile technologies.

Open University Malaysia's mission is to widen access to quality education and to provide lifelong learning opportunities by leveraging technology, by adopting flexible modes of learning, and by providing a conducive and engaging learning environment at a competitive and affordable cost. With that in mind and in line with the motto "University for All," text messaging was chosen over other mobile technology applications because it is the lowest common denominator of all mobile technologies: It can be used on all types of mobile phones and students are familiar with receiving SMSes. This is consistent with the university's philosophy of democratizing education, which means making education available to all, regardless of time, place, age, and social economic background. Further, with the high penetration rate of mobile phone subscriptions of 106.2 per 100 people in Malaysia (Malaysian Communications and Multimedia Commission, 2009), it appeared this was the way to go in making inroads into the use of mobile devices for learning among Malaysian distance learners. A "saturation of technology in the target audience" would lend a hand in bringing to scale a successful application for m-learning as advocated by Vitelli (2000), as cited in Caudill (2007).

Since its inception, the university has adopted a blended learning approach, an approach commonly used by open and distance learning higher education institutions and which, according to Melton, Graf, and Chopak-Foss (2009), has been found to be helpful in increasing retention rates. However, as indicated by OUM's cumulative attrition rate of $42.3 \%$ from the years 2001 to 2008 (Abdol Latif, Sumalee, \& Bahroom, 2009), much more needs to be done to help sustain the distance learners who are likely to feel isolated and alienated because of a lack of interaction and communication with fellow learners, tutors, and the university as compared to those in traditional universities (Hara \& Kling, 2001; Flowers, 2001; Zirkle, 2002; Dzakiria, 2005). In trying to bridge the transactional distances faced by the learners, it was noted that the university needed to provide a higher level of support to the learners more regularly and unobtrusively and to engage them psychologically by motivating and reminding them to keep pace with course schedules and requirements, as well as to help them develop self-regulation skills (Tyler-Smith, 2006; Crawford, 2008). 
Available literature records that in the last ten years, there have been numerous successful attempts by higher education institutions worldwide in using text messages to support distance learners. From Africa, these include the University of Pretoria, South Africa, and Makerere University, Uganda. From the Asia-Pacific region are the Allama Iqbal Open University of Pakistan, the Sheffield Hallam University branch in India, the Srinakharinwirot University of Thailand, the Chinese University of Hong Kong, and Box Hill Institute of TAFE, Victoria, Australia. Elsewhere, in the United Kingdom, universities that have also implemented mobile learning via SMS include Kingston University and the University of Ulster.

The universities recorded success in the following areas of support to their learners:

1. administrative support - reminding learners of contact session dates and registration deadlines, particularly those who have been missing face-to-face sessions (Ericsson Global, n.d.; Viljoen, du Preez, \& Cook, 2005; Kajumbula, 2006; Yousof, 2007; Keegan, Kismihok, Mileva, \& Rekkedal, 2009);

2. academic purposes - sending SMSes that contain important course content, which is chunked in small sizes (Uday Bhaskar \& Govindarajulu, 2008);

3. e-Counselling services (Commonwealth of Australia, 2006);

4. learner development support - helping learners to self-manage their studies better (Stone, 2001);

5. learner assessment - sending interactive quizzes for learner self-assessment (Sukaphat, 2007; Clarke, Keing, Lam, \& McNaught, 2008).

OUM's Mobile Learning via SMS was initiated in 2009 after a study that was conducted to determine the percentage of OUM learners possessing a mobile phone and the extent to which learners perceived themselves to be ready for such a project indicated that $98 \%$ of OUM learners have at least one mobile phone and approximately $82 \%$ perceived themselves to be ready for mobile learning (Abas, Chn'g, \& Mansor, 2009). Five dimensions of support were identified, namely administrative support, academic support, learner motivation enhancement, learner selfmanagement development, and learning activities co-ordination.

\section{Conceptual Model}

Under the university's blended approach to learning, undergraduate students learn via a blend of three modes: 10 hours of face-to-face tutorials per semester, self-managed learning using modules, and online learning via asynchronous forum discussions in the university's learning management system, as well as online resources such as digital learning objects. (Refer to Figure 1.) With the incorporation of mobile learning, the blended learning environment is enhanced in that the text messages (a.k.a. SMSes) give timely important information about the course, help learners to better manage their studies, motivate them, and encourage as well as remind them to tap into the three existing modes. 


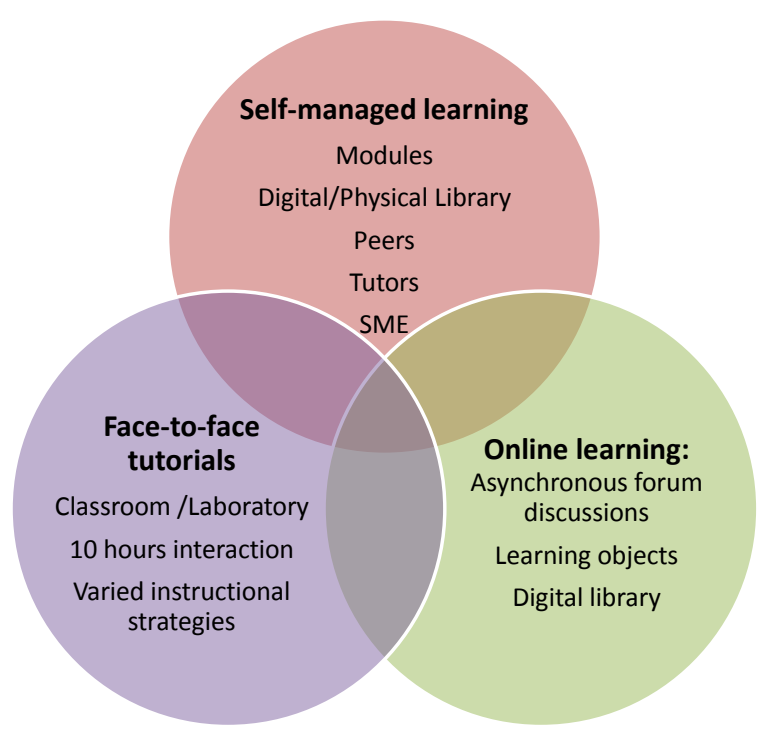

Figure 1. Blended learning approach at OUM.

Based on the recorded advantages afforded by mobile learning found in a review of related literature, five categories of SMS were identified: 1) content, 2) forum/Facebook, 3) tips, 4) motivation, and 5) course management. The five categories of text messages, their purpose, and examples are as shown in Table 1. 
Table 1

SMS Categories, Purpose, and Examples

\begin{tabular}{|c|c|c|}
\hline Category & Purpose & Example \\
\hline Content & $\begin{array}{l}\text { To help learners locate/remember } \\
\text { important course facts easily }\end{array}$ & $\begin{array}{l}\text { There are } 4 \text { pairs of learning styles: } \\
\text { Active/Reflective; Sensing/Intuitive; } \\
\text { Visual/Verbal; Sequential/Global. Which is } \\
\text { yours? See Appendix 1.1. }\end{array}$ \\
\hline Forum/Facebook & $\begin{array}{l}\text { To remind and motivate learners to } \\
\text { participate in discussion forums }\end{array}$ & $\begin{array}{l}\text { Would you consider Tony Fernandez a } \\
\text { successful entrepreneur? Why do you say so? } \\
\text { Post your views in LMS forum. }\end{array}$ \\
\hline Tips & $\begin{array}{l}\text { To provide hints/strategies on how } \\
\text { to do well in their studies }\end{array}$ & $\begin{array}{l}\text { Revise focus assessment for renal patients and } \\
\text { effective nurse-client communication in } \\
\text { preparation for OSCE. }\end{array}$ \\
\hline Motivation & $\begin{array}{l}\text { To motivate learners to persevere in } \\
\text { the learning process }\end{array}$ & $\begin{array}{l}\text { To succeed, we must first believe that we can. } \\
\text { By Michael Korda. Always believe in yourself } \\
\text { :-). }\end{array}$ \\
\hline $\begin{array}{l}\text { Course } \\
\text { management }\end{array}$ & $\begin{array}{l}\text { To provide timely } \\
\text { announcements/reminders related to } \\
\text { tutorials/assessments }\end{array}$ & $\begin{array}{l}\text { Your assignment is due next week. Remember } \\
\text { to submit by T4. Best wishes! }\end{array}$ \\
\hline
\end{tabular}

In the May 2010 semester, interactive SMS applications were developed so that learners could respond to the SMSes received. Two types of interactive SMS application used are as shown in Table 2. 
Table 2

Interactive SMS Applications

\begin{tabular}{|c|c|c|}
\hline & Sequence of events & Example \\
\hline 1. & \multicolumn{2}{|c|}{ Survey Question and Response } \\
\hline a. & $\begin{array}{l}\text { OUM sends a survey } \\
\text { item }\end{array}$ & $\begin{array}{l}\text { Dear OUM learner, if you do NOT wish to receive anymore } \\
\text { Mobile Learning SMS for OUMH1103, please key in OUM } \\
\text { OUMH1103 STOP and send to } 32255 \text {. }\end{array}$ \\
\hline b. & Student responds & \\
\hline c. & OUM replies & $\begin{array}{l}\text { Thank you for your SMS. You will discontinue receiving the } \\
\text { Mobile Learning SMSes within a week. Best wishes from OUM. }\end{array}$ \\
\hline 2. & \multicolumn{2}{|c|}{ Multiple Choice Questioning, Response, \& Feedback } \\
\hline a. & $\begin{array}{l}\text { OUM sends a } \\
\text { multiple choice } \\
\text { question with } 4 \\
\text { answer options }\end{array}$ & $\begin{array}{l}\text { What TQM area of focus refers to employee authority to make } \\
\text { decisions? } \\
\text { A. Training } \\
\text { B. Empowerment } \\
\text { C. Involvement } \\
\text { D. Recognition }\end{array}$ \\
\hline b. & $\begin{array}{l}\text { Instruction on how to } \\
\text { respond }\end{array}$ & $\begin{array}{l}\text { To check your answer, key in OUM OUMM2103 A, B, C or D } \\
\text { and send to } 32255 .\end{array}$ \\
\hline c. & Student responds & \\
\hline d. & OUM sends feedback & $\begin{array}{l}\text { A : Sorry, your answer is incorrect. The correct answer is B. } \\
\text { Empowerment is the authority to take control and make decisions. } \\
\text { B : That is correct! Empowerment is the authority to take control } \\
\text { and make decisions. Congratulations! } \\
\text { C : Sorry, your answer is incorrect. The correct answer is B. } \\
\text { Empowerment is the authority to take control and make decisions. } \\
\text { D : Sorry, your answer is incorrect. The correct answer is B. } \\
\text { Empowerment is the authority to take control and make decisions. }\end{array}$ \\
\hline
\end{tabular}




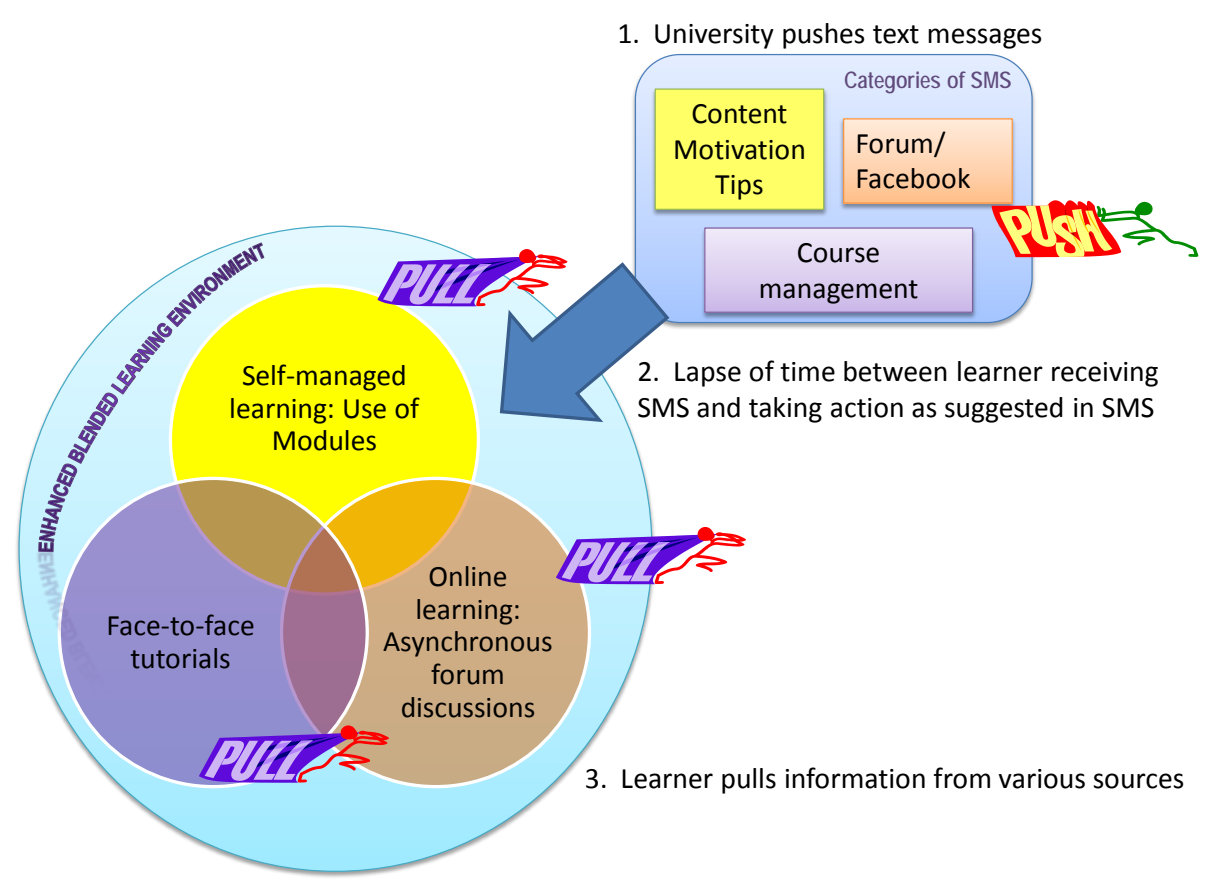

Figure 2. Enhanced blended learning environment.

In essence, when the university sends the text messages to learners, unsolicited information is pushed to learners outside normal interaction hours and communication spaces. Upon receiving the SMS, learners may choose to respond by 'pulling' information immediately, or if they are busy with work or family commitments, they may opt to do that at a later time when they are free. The type of action that learners engage in depends on the category of SMS received. If a contentrelated SMS is received, they may 'pull' information from their modules, or if they are not clear on course concepts, they can seek further clarification/explanation from their tutors during faceto-face tutorials. However, if they receive a text message encouraging them to discuss in online forums/Facebook, learners may log onto the asynchronous forums to interact with their peers or tutors. Besides extending learning space, the other advantage afforded by mobile learning is that it facilitates "just-in-time” learning and lends more flexibility to the whole learning process.

\section{Courses Involved}

The courses for which Mobile Learning were offered are as shown in Table 3. 
Table 3

Details of Mobile Learning Courses

\begin{tabular}{|c|c|c|c|}
\hline Semester & $\begin{array}{l}\text { Course Code } \\
\text { Course }\end{array}$ & $\begin{array}{l}\text { No. of learners } \\
\text { involved }\end{array}$ & $\begin{array}{l}\text { No. of } \\
\text { SMSes } \\
\text { sent per } \\
\text { course }\end{array}$ \\
\hline MAY 2009 & $\begin{array}{l}\text { OUMH } 1103 \\
\text { Learning Skills for ODL }\end{array}$ & 1863 & 31 \\
\hline \multirow[t]{3}{*}{ SEPT 2009} & $\begin{array}{l}\text { OUMH } 1103 \\
\text { Learning Skills for ODL }\end{array}$ & 1173 & 25 \\
\hline & $\begin{array}{l}\text { BBUS } 2103 \\
\text { Company Law }\end{array}$ & 243 & 31 \\
\hline & $\begin{array}{l}\text { NBNS } 3504 \\
\text { Renal Nursing }\end{array}$ & 318 & 30 \\
\hline \multirow[t]{6}{*}{ JAN 2010} & $\begin{array}{l}\text { OUMH } 1103 \\
\text { Learning Skills for ODL }\end{array}$ & 1942 & 29 \\
\hline & $\begin{array}{l}\text { BBMA } 3103 \\
\text { Management Accounting } 1\end{array}$ & 93 & 26 \\
\hline & $\begin{array}{l}\text { CBCP } 2103 \\
\text { Computer Programming }\end{array}$ & 149 & 28 \\
\hline & $\begin{array}{l}\text { HBCA } 2103 \\
\text { Principles of Advertising }\end{array}$ & 27 & 22 \\
\hline & $\begin{array}{l}\text { NBNS } 2804 \\
\text { Mental Health Nursing }\end{array}$ & 89 & 32 \\
\hline & $\begin{array}{l}\text { SBBI } 4203 \\
\text { General Genetics }\end{array}$ & 346 & 21 \\
\hline \multirow[t]{3}{*}{ MAY 2010} & $\begin{array}{l}\text { OUMH } 1103 \\
\text { Learning Skills for ODL }\end{array}$ & 1477 & 25 \\
\hline & $\begin{array}{l}\text { OUMH } 1203 \\
\text { English for Written Communication }\end{array}$ & 2961 & 25 \\
\hline & $\begin{array}{l}\text { OUMM } 2103 \\
\text { Entrepreneurship }\end{array}$ & 1857 & 29 \\
\hline $\begin{array}{l}\text { SEPT } \\
2010\end{array}$ & $\begin{array}{l}\text { MPW1133/2133 } \\
\text { Malaysian Studies } \\
\text { (fully online) }\end{array}$ & 196 & 20 \\
\hline
\end{tabular}

\section{Learner Support}

To take advantage of popular Web 2.0 technologies, Facebook and Twitter were used to support this initiative; Facebook provided an alternative platform to the normal asynchronous online 
forums in the university's learning management system for learners to discuss related content, while Twitter was used to archive the SMSes sent. Throughout the initiative, learner support was

provided in the form of telephone and email helplines. Guidelines in OUM's learning management system covered reporting non-receipt of SMSes, accessing and interacting in Facebook, and updating mobile phone numbers. Approximately midway through the semester, learners were given the option to stop receiving the SMSes. Thus far, less than $5 \%$ of the learners have chosen to do so in any one semester.

\section{Process Flow}

The process flow for group messaging is as shown in Figure 3. Prior to the start of each semester, the Mobile Learning via SMS team together with the subject matter experts develop the SMS schedule and content (see sample in Figure 4.) Mobile phone numbers of learners are also obtained from the Registry database and .txt files are prepared using Notepad for incorporation in the university's group messaging application known as OUM Workmate (see Figure 5.) During the academic semester, individual text messages are copied and pasted into Workmate and set to be sent at a predetermined delayed date and time. In addition, delivery of the SMSes is monitored and technical problems that arise such as non-delivery or late delivery of SMSes are noted, and the frequency of such occurrences are analysed. Finally, at the end of each semester, the effectiveness of the initiative in supporting our distance learners is evaluated. 
OUM SMS

Application

Bulk SMS

Gateway

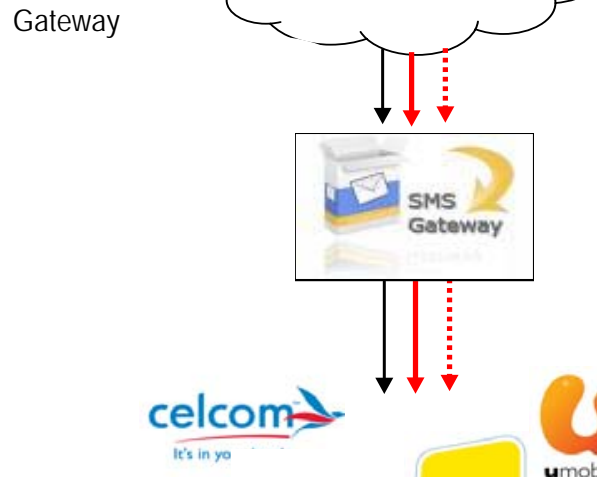

Local TelCo

operators
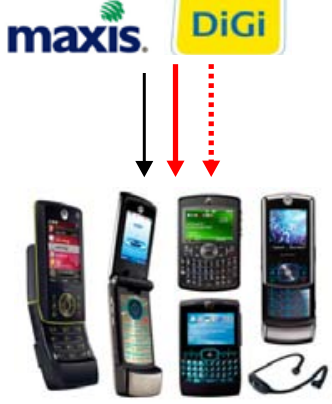

Obtain learners' mobile phone number from Registry database

Prepare .txt file

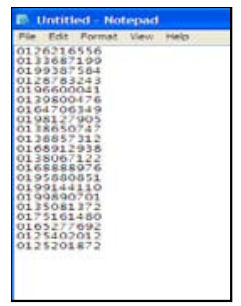

Key in SMS, set delivery date and time

Process flow of interactive SMS

Process flow of interactive SMS when learners respond

Figure 3. Process flow diagram. 


\begin{tabular}{|c|c|c|c|}
\hline DAYS & $\begin{array}{l}\text { Week } 1 \text { (21 - } 27 \text { Sept 2009) } \\
\text { (Before T1) }\end{array}$ & $\begin{array}{c}\text { Week } 2 \text { (28 Sept - } 4 \text { Oct 2009) } \\
\text { (Topic 1- Introduction to Company } \\
\text { Law) }\end{array}$ & $\begin{array}{c}\text { Week } 3(5-11 \text { Oct 2009) } \\
\text { (Topic 1- Introduction to Company } \\
\text { Law) }\end{array}$ \\
\hline MONDAY & HARI RAYA PUASA & $\begin{array}{l}\text { There are } 4 \text { types of business structure in } \\
\text { Malaysia. Discuss the advantages and } \\
\text { disadvantages of each type in the forum. } \\
\text { Refer to } 1.2 \text { and } 1.3\end{array}$ & $\begin{array}{l}\text { Is the company liable for all contracts } \\
\text { entered into by promoter before } \\
\text { incorporation of the company? Refer to } \\
1.8 .4\end{array}$ \\
\hline TUESDAY & $\begin{array}{l}\text { HARI RAYA PUASA } \\
\text { Welcome back to OUM! You will be } \\
\text { receiving a series of SMSes for Company } \\
\text { Law as part of our value added service. } \\
\text { It is free. Enjoy! }\end{array}$ & 29 & 6 \\
\hline WEDNESDAY & $\begin{array}{l}\text { Do you know that learning is an active } \\
\text { process? We learn by doing. Only } \\
\text { knowledge that is used sticks in your } \\
\text { mind. Dale Carnegie }\end{array}$ & $\begin{array}{l}\text { What are the effects of incorporation to } \\
\text { a company according to the Companies } \\
\text { Act 1965? Refer to } 1.4 .5\end{array}$ & $\begin{array}{l}\text { Why is partnership business structure } \\
\text { very popular among entrepreneurs in ? } \\
\text { Discuss in myLMS forum. Refer to 1.3.2 }\end{array}$ \\
\hline THURSDAY & $\begin{array}{l}\text { Your tutor is very keen to meet you } \\
\text { during tutorials. Welcome you all and be } \\
\text { on time. See you! }\end{array}$ & \begin{tabular}{|l|}
1 \\
Hi, try to read your module regularly and \\
participate actively in the forum. This \\
will help you do well in your studies. :-) \\
\end{tabular} & 8 \\
\hline $\begin{array}{l}\text { FRIDAYISATI } \\
\text { SUNDAY }\end{array}$ & $\begin{array}{c}\text { TUTORIAL } 1 \\
\text { (25-27 Sept 2009) }\end{array}$ & 2 & $\begin{array}{c}\text { TUTORIAL } 2 \\
\text { (9-11 Sept 2009) }\end{array}$ \\
\hline
\end{tabular}

Figure 4. Sample SMS Content and Schedule.

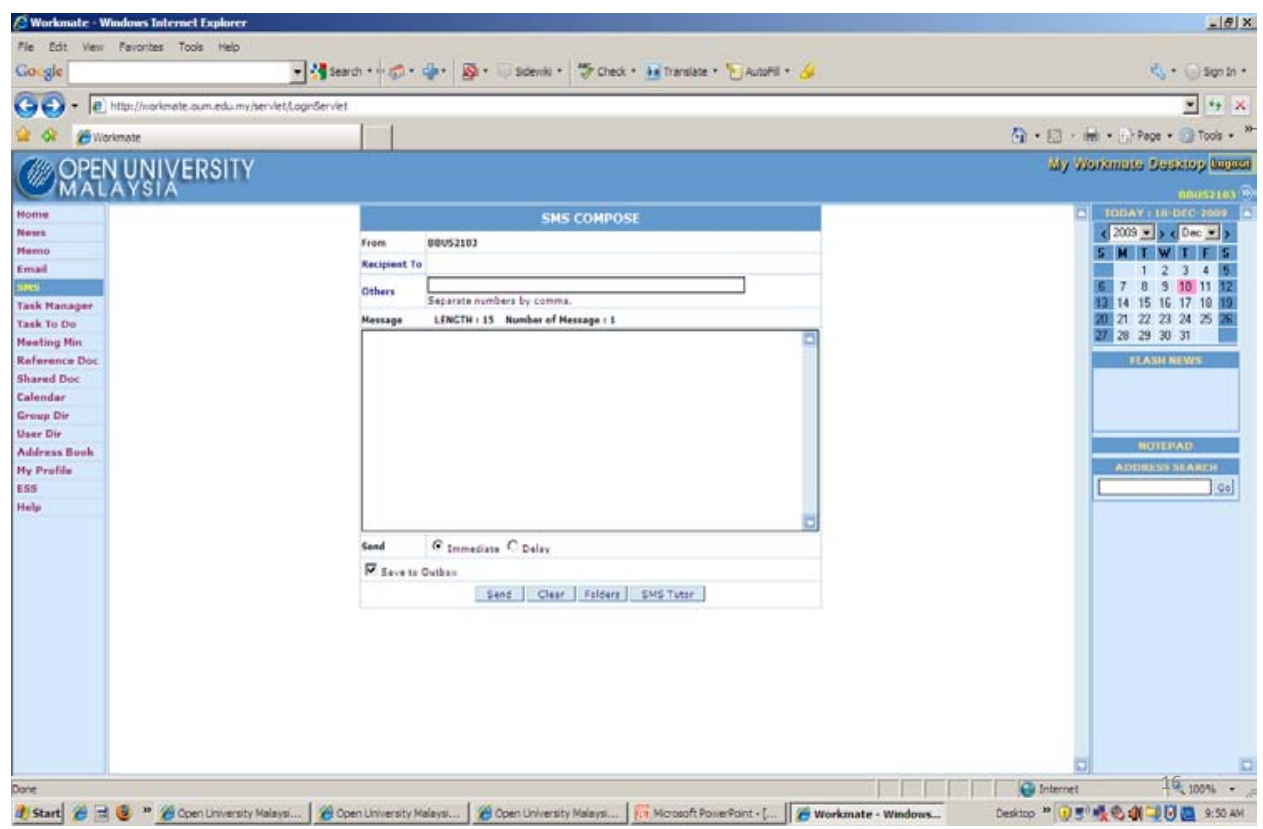

Figure 5. Screen capture of OUM’s Workmate (Group messaging application). 


\section{Challenges}

When developing the text messages, the number of characters available is currently only 134 (145 prior to the September 2010 semester, i.e., before the standard change in short code which requires RM0.00 to be shown if the cost of the SMS sent is borne by the sender). This is markedly less than that available in normal SMSes because when using group messaging via the bulk SMS gateway, several characters are taken up in showing the short code involved (e.g., RM0.00 OUM OUMH1103). Thus, when developing the SMS content, much care has to be taken in ensuring the message is meaningful yet concise and the language used is simple. In order to discourage learners from thinking that short forms are acceptable in written documents, abbreviations like 'tq' are not used unless absolutely necessary, that is, when the number of characters for a particular message already exceeds the limit.

Further, some technical issues that have surfaced during implementation of the initiative include non-delivery or late delivery of SMSes either due to problems at the bulk SMS gateway provider or because of service glitches at certain telecommunication providers. When a message is not received at the targeted time, the Mobile Learning team generally waits until the following day to see if it is a permanent failure. In such cases, the same message will be reset for the following day and the subsequent SMS is also rescheduled if it was scheduled for the day after the failed SMS.

\section{Effectiveness of the Initiative}

Findings from summative evaluations of the initiative have consistently shown that learners appreciated the text messages and felt that the SMSes had helped them to stay focused and engaged in their studies. The messages were also useful in providing important information related to the course. Additionally, in general, the learners agreed that the messages had allowed them to learn anytime and anywhere and had helped them manage their studies better (Abas, Lim, \& Woo, 2009; Abas, Lim, Singh, \& Wei, 2009; Singh, 2010; Abas, Lim, \& Ramly, in press). Every semester over 95\% of the learners involved expressed their wish that Mobile Learning via SMS be extended to other courses as well.

In monetary terms, the cost of sending one SMS is 20 sen. Thus, for an average of 25 SMSes to a single learner for one course per semester, the cost borne by the university is RM5.00. If one were to compare that to the benefits of possible successful retention and progress of a learner in his/her studies, one might safely say it is a great investment in terms of ensuring learner success and satisfaction. While it is noted that a proper cost-effectiveness study on the use of SMS in retaining students and recouping costs would be able to shed light on how viable the initiative is, it ought to be also emphasized that not all things valued may be measured in monetary terms. Helping even a single learner to enjoy and succeed in learning is what counts for a responsible distance education provider. 


\section{Conclusion}

Mobile learning via SMS helps reduce the transactional distance of psychological and communication space often faced by distance learners who are separated in terms of geographical distance and time (Moore, 1997). It also enables the university to reach out to learners outside of conventional communication spaces, and it helps to keep learners connected to the university, their peers, and their tutors.

As the project has been found to be sustainable in terms of costs, efforts, and resources, the university plans to further extend the service to other courses, in particular those that will be conducted fully online.

\section{Acknowledgement}

The authors wish to acknowledge all members of Open University Malaysia's Mobile Learning team for their esteemed collaborative efforts, enthusiasm, and commitment throughout the planning and implementation stages of this initiative since its inception. 


\section{References}

Abas, Z. W., Chng, L. P., \& Mansor, N. (2009). A study on learner readiness for mobile learning at Open University Malaysia. In Proceedings of IADIS International Conference Mobile Learning (pp. 151-157).

Abas, Z. W., Lim, T., \& Woo, T. K. (2009). Mobile learning initiative through SMS: A formative evaluation. ASEAN Journal of Open and Distance Learning, 1 (1), 49-58. Retrieved from http://ajodl.oum.edu.my/fajodl/201007/15070126Article_6.pdf.

Abas, Z. W., Lim, T., Singh, H. K. D., \& Wei, W. S. (2009). The design and implementation of mobile learning at Open University Malaysia. In Proceedings of the South-east Asia Association for Institutional Research Conference 2009, Penang. 13-15 October 2009.

Abas, Z. W., Lim, T., \& Ramly, R. (in press). Unleashing the potential of mobile learning through SMS text for open and distance learners. In A. Kitchenham (Ed.), Models for interdisciplinary mobile learning: Delivering information to students. Hershey, PA: IGI Global.

Abdol Latif, L., Sumalee, S., \& Bahroom, R. (2009). Managing retention in ODL institutions: A case study on Open University Malaysia and Sukothai Thammathirat Open University. ASEAN Journal of Open and Distance Learning, 1(1), 1-10. Retrieved from http://ajodl.oum.edu.my/fajodl/201007/15072338Article_1.pdf .

Caudill, J. G. (2007). The growth of m-learning and the growth of mobile computing: Parallel developments. International Review of Research in Open and Distance Learning, 8(2). Retrieved from http://www.irrodl.org/index.php/irrodl/article/view/348/873

Clarke, P., Keing, C., Lam, P., \& McNaught, C. (2008). Using SMSs to engage students in language learning. In E. R. Weipp \& J. Luca (Eds.), ED-MEDIA 2008 (pp. 6132-6141). Proceedings of the 20th annual World Conference on Educational Multimedia, Hypermedia \& Telecommunications, Vienna, Austria, 30 June-4 July. Chesapeake VA: Association for the Advancement of Computers in Education.

Commonwealth of Australia. (2006). Australian Flexible Learning Framework. Retrieved from http://pre2009.flexiblelearning.net.au/flx/webdav/site/flxsite/shared/Inclusive\%20Elearning/Box_Hill_case_study_06.pdf

Crawford, C. M. (2008). Belonging and identity: Creating and sustaining communities of learning within distance learning environments, while focusing upon making connections, creating communities of learning, and maintaining personal and professional identities. Paper presented at the Fourth International Conference on Environmental, Cultural, Economic \& Social Sustainability. 4-7 January 2008. Universiti Malaysia Terengganu. 
Dzakiria, H. (2005). The role of learning support in open and distance learning: Learners' experiences and perspectives. Turkish Online Journal of Distance Education (TOJDE). Retrieved from http://tojde.anadolu.edu.tr/tojde18/articles/article4.htm

Ericsson Global. (n.d.). Achievements of mobile learning today. Retrieved from http://www.ericsson.com/ericsson/corpinfo/programs/the_role_of_mobile_learning_in_eu ropean_education/products/workpackage2.shtml

Flowers, J. (2001). Online learning needs in technology education. Journal of Technology Education, 13(1), 17-30.

Hara, N., \& Kling, R. (2001). Student distress in web-based distance education. Educause Quarterly, 3, 68-69.

Kajumbula, R. (2006). The effectiveness of mobile short messaging service (SMS) technologies in the support of selected distance education students of Makerere University, Uganda. Paper presented at PCF4, the Fourth Pan-Commonwealth Forum on Open Learning, Jamaica, 30 October-3 November 2006. Retrieved from http://pcf4.dec.uwi.edu/viewpaper.php?id=98\&print=1 .

Keegan, D., Kismihok, G., Mileva, N., \& Rekkedal, T. (2009). The role of mobile learning in European education. Retrieved from http://www.ericsson.com/ericsson/corpinfo/programs/the_role_of_mobile_learning_in_eu ropean_education/products/workpackage4.shtml

Malaysian Communications and Multimedia Commission. (2009). Penetration rates at a glance. Retrieved from http://register.skmm.gov.my/facts_figures/stats/ViewStatistic.asp?cc=36702694\&srid=50 $\underline{919742}$

Melton, B., Graf, H., \& Chopak-Foss, J. (2009). Achievement and satisfaction in blended learning versus traditional general health course designs. International Journal for the Scholarship of Teaching and Learning, 3(1). Retrieved from http://academics.georgiasouthern.edu/ijsotl/v3n1/articles/_MeltonGrafChopakFoss/index.htm

Moore, M. (1997). Theory of transactional distance. In D. Keegan (Ed.), Theoretical principles of distance education (pp. 22-38). New York: Routledge.

Singh, H. K. D. (2010, June). Effectiveness of 5-category pedagogical model using SMS technology. Paper presented at the International Conference on Communication and Media, Melaka, Malaysia. 
Stone, A. (2001). Mobile scaffolding: An experiment in using SMS text messaging to support first year university students. Proceedings from the Fourth IEEE International Conference on Advanced Learning Technologies (ICALT'04), 30 August-1 September 2004 (pp. 405-409).

Sukaphat, S. (2007). Applying of bulk SMS system to enhance educational communications. Proceedings of the 13th Asia Pacific Management Conference, Melbourne, Australia, 2007 (pp. 582-586). Retrieved from http://mlearning.danysto.info/library/files/a267.pdf

Tyler-Smith, K. (2006). Early attrition among first time e-learners: A review of factors that contribute to drop-out, withdrawal and non-completion rates of adult learners undertaking e-learning programmes. Journal of Online Learning and Teaching, 2(2). Retrieved from http://jolt.merlot.org/Vol2_No2_TylerSmith.htm

Uday Bhaskar, N., \& Govindarajulu, P. (2008). Implications of mobile technology usage on learners in a learning process. International Journal of Computer Science and Network Security, 8(5), 251-259.

Viljoen, J., du Preez, C., \& Cook, A. (2005). The case for using SMS technologies to support distance education students in South Africa: Conversations. Perspectives in Education, 23(4), 115-122.

Yousof, (2007). Effectiveness of mobile learning in distance education. Turkish Online Journal of Distance Education, 8(4). Retrieved from http://tojde.anadolu.edu.tr/tojde28/articles/article_9.htm

Zirkle, C. (2002). Identification of distance education barriers for trade and industrial teacher education. Journal of Industrial Teacher Education, 40(1), 20-44.

\section{Athabasca University $\mathbf{a}$}

